\title{
Trends in chlamydia positivity among heterosexual patients from the Victorian Primary Care Network for Sentinel Surveillance, 2007-2011
}

\section{Megan S C Lim PhD, BBiomedSci(Hons) Research Fellow \\ Carol El-Hayek BSC, MEpi, Infectious Diseases Surveillance Manager \\ Jane L Golle RN, MPH, MHIthSci Research Officer \\ Christopher K Fairley Professor of Sexual Health, and Director ${ }^{3}$ \\ Phuong LT Nguyen BBiomedSci(Hons) Research Assistant ${ }^{1}$ \\ Rochelle A Hamilton MHlthSci, \\ Manager/Clinical Nurse Consultant ${ }^{4}$ \\ Dorothy J Henning GD-ADOLHW, MNurs, Youth Health Nurse Practitioner \\ Kathleen M McNamee MB BS, FRACGP, MEpi, Medical Director, ${ }^{6}$ and Adjunct Senior Lecturer \\ Margaret E Hellard FRACP, FAFPHM, PhD, \\ Head
A toove \\ Mark A Stoove
(1) Head, HIV Research \\ 1 Centre for Population Health, Burnet Institute, Melbourne, VIC. \\ 2 Melbourne School of Population and Global Health, \\ University of Melbourne, Melbourne, VIC. \\ 3 Melbourne Sexual Health Centre, Melbourne, VIC. \\ 4 Barwon Reproductive and \\ Sexual Health Clinic, Barwon Health, Melbourne, VIC. \\ 5 Young People's Health Service, Centre fo Adolescent Health \\ Royal Children's Hospital, Melbourne, VIC. \\ 6 Family Planning Victoria Melbourne, VIC \\ 7 Department of Obstetrics and Gynaecology, Monash University, Melbourne, VIC \\ lim@burnet.edu.au}

MJA 2014; 200: 166-169 doi: $10.5694 / \mathrm{mjal} 3.10108$ hlamydia is the most commonly notified infectious disease in Australia, predominantly diagnosed among young heterosexual populations. The number of infections diagnosed each year in Victoria has increased steadily, from 11149 in 2007 to 19834 in 2012. ${ }^{1}$ In recent years, multiple interventions have been conducted nationally, aimed at increasing rates of testing for chlamydia. $^{2-8}$ In combination with policy and practice change, these interventions have been successful in nearly doubling the number of chlamydia tests conducted in Australia from 161550 in 2007 to 299685 in $2012 .^{9}$

Increased testing could explain rising notifications; however, it is important to determine whether chlamydia prevalence is also increasing. There is some evidence from clinic-based surveillance that the prevalence of chlamydia in the population is rising. ${ }^{10-13}$ However, existing studies have all been based on sexual health clinic attendees only, which account for less than $2 \%$ of chlamydia diagnoses in Australia. ${ }^{14}$ Further, only one of these studies included data on heterosexual clients from multiple clinics, and it did not report on or adjust trends for reported sexual behaviours. ${ }^{13}$

Sentinel surveillance through primary health care clinics offers an opportunity to collect information on those being tested for chlamydia and provide ongoing estimates of chlamydia positivity and correlates of infections detected. When testing rates are sufficiently high, chlamydia positivity in clinics can be an accurate indicator of chlamydia prevalence in the population being tested. ${ }^{15}$ We aimed to determine whether chlamydia positivity is increasing among heterosexual people tested for chlamydia at a number of sentinel surveillance clinics in Victoria, taking into account sexual behaviours.

\begin{abstract}
Objective: To describe trends in chlamydia positivity from 2007 to 2011 among heterosexual people tested for chlamydia at selected clinics that provide services to people at high risk in Victoria, Australia.

Design: The Victorian Primary Care Network for Sentinel Surveillance is a prospective system that collates pathology results from laboratories and demographic and behavioural data from a questionnaire.
\end{abstract}

Setting: Two sexual health clinics and six other primary care clinics that target young people and women at high risk.

Participants: All clients tested for chlamydia at sentinel clinics. Individuals aged less than 16 years, sex workers, or those reporting any same-sex sexual partners in the past 12 months were excluded from the analysis.

Main outcome measures: Chlamydia positivity trends were assessed using three-level random-effects Poisson regression, with clinic and subject treated as nested random factors. Models were offset for total number of tests and adjusted for relevant covariates.

Results: Between 2007 and 2011, chlamydia positivity among 31682 tests in women increased from $5.1 \%$ to $6.3 \%$, and positivity among 23771 tests in men increased from $7.4 \%$ to $8.2 \%$. Adjusting for age, country of birth, number of sex partners, condom use, and presence of symptoms, chlamydia positivity increased between 2007 and 2011 significantly among women (incidence rate ratio [IRR], 1.29; 95\% CI, 1.11-1.50) and non-significantly among men (IRR, 1.07; $95 \% \mathrm{Cl}, 0.92-1.23$ ). Over time, a decrease in reported inconsistent condom use was also observed in both men and women; however, men became more likely to report more than one partner in the past year.

Conclusion: We identified a concerning increase in chlamydia positivity over time, particularly among young women.

\section{Methods}

The Victorian Primary Care Network for Sentinel Surveillance on bloodborne viruses and sexually transmitted infections (STIs) collects data on all clients tested for Chlamydia trachomatis at selected clinics treating people at high risk of STIs. ${ }^{16}$ Eight sites collect data on heterosexual clients; these sites include two sexual health clinics and six other primary care clinics providing services to young people at high risk. The latter include family planning, hospital, community and correctional facility clinics, which opportunistically screen patients for chlamydia based on the chlamydia risk factors of the individuals presenting. These clinics see caseloads of homeless and incarcerated youth, young pregnant women, young women with fertility issues and individuals referred by their infected partners.
Demographic and behavioural data were collected using a questionnaire from all patients undergoing chlamydia testing as part of standard clinical practice. The reason for the patient's visit and STI test was asked. Responses were coded as: asymptomatic, patient-initiated; asymptomatic, doctor-initiated; STI symptoms present; other reason. Symptoms were not defined and may have been unrelated to chlamydia. Chlamydia polymerase chain reaction results were collected directly from the laboratories servicing the sentinel sites and were linked to questionnaire records.

For analysis, indeterminate chlamydia results were excluded. All test results from the same individual within 30 days were excluded as these may not reflect new tests. Subjects could have multiple tests across the study period (2007-2011). Patients aged less than 16 years, those report- 
1 Number of chlamydia tests and percentage of positive results, by year and sex

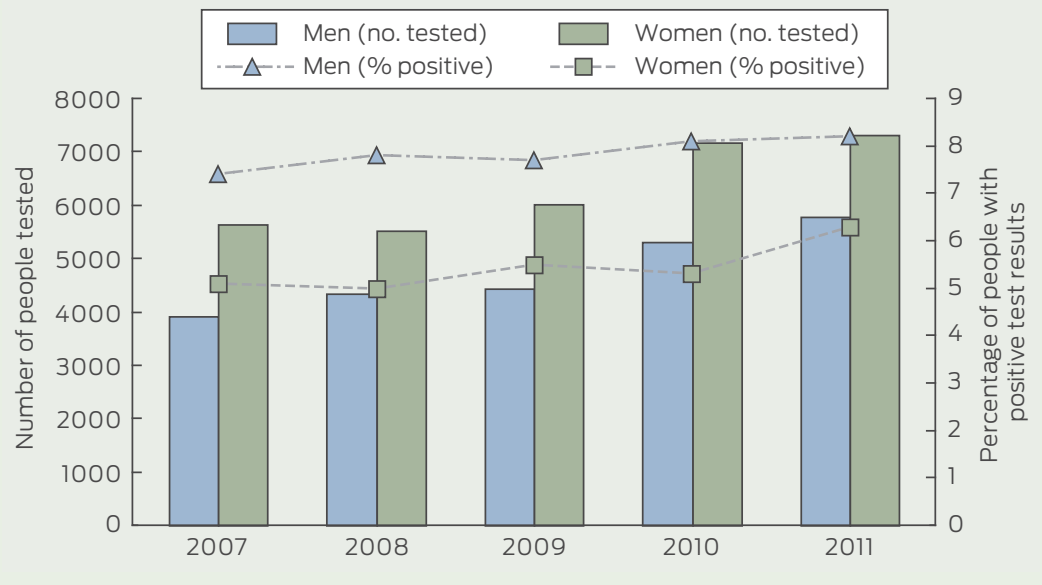

ing sex work, or those reporting any same-sex sexual partners in the past 12 months were excluded from analysis. Trends in test numbers were determined using linear regression. Changes from baseline (2007) in incidence of testing positive were assessed using three-level randomeffects Poisson regression models, with clinic and subject treated as nested random factors to account for dependencies across these levels. Wald tests were undertaken to compare rates between subsequent years. Models were offset for total number of tests and adjusted for relevant covariates (age group, being born overseas, symptoms, more than one sexual partner in the past year, and inconsistent condom use). Covariates were included based on previously reported risk factor analyses. ${ }^{17}$ Differences in risk groups over time were explored by bivariate logistic regression analyses, with standard errors adjusted for clustering by clinic. Only a single record per person per year was included in risk group analysis. Analyses were conducted in Stata version 11 (StataCorp).

The project was approved by the Department of Health Human Research Ethics Committee. The individual ethics committees of all sentinel sites were consulted.

\section{Results}

Over 5 years (2007-2011), there were 31682 chlamydia tests among women and 23771 tests among men. The number of people tested each year increased over time by an average of
498 women per year (95\% CI, 126$870)$ and 467 men per year (95\% CI, 258-676) (Box 1).

Fifty-three per cent of women and $32 \%$ of men tested were under 25 years of age. Among women, 54\% of tests were conducted at a sexual health clinic and $46 \%$ at other sites; among men, $91 \%$ of tests were conducted at a sexual health clinic.

\section{Women}

The overall percentage of women with positive test results for chlamydia was $5.5 \% \quad(95 \%$ CI, $5.2 \%-5.7 \%)$. This increased from $5.1 \%$ in 2007 to $6.3 \%$ in 2011 (incidence rate ratio [IRR], 1.31; 95\% CI, 1.13-1.52) (Box 1). Only rates in 2011 were significantly different than the previous year $(P<0.05)$.

When stratified by age group, an increase in chlamydia positivity from 2007 was observed in women aged 16 to 19 years and those over 35 years (Box 2). Adjusting for age, country of birth, number of sex partners, condom use and presence of symptoms, chlamydia positivity increased between 2007 and 2011 (IRR, 1.29; 95\% CI, 1.11-1.50).

Box 3 shows trends in the risk profile of women tested for chlamydia. Compared with 2007, the proportion of women born overseas increased over time, and the proportion reporting inconsistent condom use declined.

\section{Men}

The overall percentage of men with positive test results for chlamydia was 7.9\% (95\% CI, 7.5\%-8.3\%). Positivity among men increased slightly from
$7.4 \%$ in 2007 to $8.2 \%$ in 2011 (IRR, 1.10; 95\% CI, 0.95-1.28) (Box 1).

When stratified by age group, only men aged over 35 years showed a significant change in likelihood of having positive test results for chlamydia (Box 2). Adjusting for age, country of birth, number of sex partners, condom use, and presence of symptoms, likelihood of testing positive slightly increased between 2007 and 2011 (IRR, 1.07; 95\% CI, 0.92-1.23).

Box 3 shows trends in the risk profile of men tested for chlamydia. Compared with 2007, there was an increase in the percentage of men tested who were born overseas and those who reported having more than one sexual partner in the past year. Inconsistent condom use declined over time.

\section{Discussion}

This analysis has shown a significant increase in the number of people tested for chlamydia at sentinel clinics between 2007 and 2011. Testing alone cannot explain the increase in positive results over time, as a significant increase was also observed in the percentage of positive chlamydia tests among women. Chlamydia positivity was highest in younger women, aged 16-19 years, increasing significantly over time and peaking in 2011, when one in 10 teenage young women tested were diagnosed with chlamydia. Although positivity also increased in women aged over 35 years, it remained much lower than in young women. There was only a marginal non-significant increase in chlamydia positivity among men. For both men and women, trends persisted after adjusting for age, country of birth, number of sex partners, condom use and presence of symptoms.

The observed increase in chlamydia positivity may be due to a true increase in chlamydia prevalence in the population or may be a result of the methods used in this surveillance system. System limitations mean that we cannot be certain that observed trends reflect population trends. The system only includes patients who sought medical attention and had chlamydia testing at one of the sentinel clinics. The selected sentinel sites 
2 People tested for chlamydia, number and percentage positive, and change from baseline (2007) in likelihood of having a positive test result, by sex, year and age group

\begin{tabular}{|c|c|c|c|c|c|c|c|c|c|c|c|c|c|c|}
\hline \multirow[b]{2}{*}{$\begin{array}{l}\text { Sex and } \\
\text { age in } \\
\text { years }\end{array}$} & \multicolumn{2}{|c|}{2007} & \multicolumn{3}{|c|}{2008} & \multicolumn{3}{|c|}{2009} & \multicolumn{3}{|c|}{2010} & \multicolumn{3}{|c|}{2011} \\
\hline & $\begin{array}{l}\text { No. } \\
\text { tested }\end{array}$ & $\begin{array}{l}\text { No. (\%) } \\
\text { positive }\end{array}$ & $\begin{array}{l}\text { No. } \\
\text { tested }\end{array}$ & $\begin{array}{l}\text { No. (\%) } \\
\text { positive }\end{array}$ & $\begin{array}{c}\text { Change from } \\
\text { 2007: IRR } \\
(95 \% \mathrm{Cl})\end{array}$ & $\begin{array}{c}\text { No. } \\
\text { tested }\end{array}$ & $\begin{array}{l}\text { No. (\%) } \\
\text { positive }\end{array}$ & $\begin{array}{c}\text { Change from } \\
\text { 2007: IRR } \\
(95 \% \mathrm{Cl})\end{array}$ & $\begin{array}{c}\text { No. } \\
\text { tested }\end{array}$ & $\begin{array}{l}\text { No. (\%) } \\
\text { positive }\end{array}$ & $\begin{array}{c}\text { Change from } \\
\text { 2007: IRR } \\
(95 \% \mathrm{Cl})\end{array}$ & $\begin{array}{l}\text { No. } \\
\text { tested }\end{array}$ & $\begin{array}{l}\text { No. (\%) } \\
\text { positive }\end{array}$ & $\begin{array}{c}\text { Change from } \\
\text { 2007: IRR } \\
(95 \% \mathrm{Cl})\end{array}$ \\
\hline \multicolumn{15}{|l|}{ Female } \\
\hline $16-19$ & 1142 & $\begin{array}{c}84 \\
(7.4 \%)\end{array}$ & 1032 & $\begin{array}{c}69 \\
(6.7 \%)\end{array}$ & $\begin{array}{c}0.8 \\
(0.6-1.2)\end{array}$ & 1055 & $\begin{array}{c}81 \\
(7.7 \%)\end{array}$ & $\begin{array}{c}1.0 \\
(0.7-1.4)\end{array}$ & 1289 & $\begin{array}{c}114 \\
(8.8 \%)\end{array}$ & $\begin{array}{c}1.6 \\
(1.2-2.1)\end{array}$ & 1416 & $\begin{array}{c}140 \\
(9.9 \%)\end{array}$ & $\begin{array}{c}2.0 \\
(1.5-2.6)\end{array}$ \\
\hline $20-24$ & 2002 & $\begin{array}{c}128 \\
(6.4 \%)\end{array}$ & 1901 & $\begin{array}{c}125 \\
(6.6 \%)\end{array}$ & $\begin{array}{c}0.9 \\
(0.7-1.1)\end{array}$ & 2086 & $\begin{array}{c}158 \\
(7.6 \%)\end{array}$ & $\begin{array}{c}0.9 \\
(0.7-1.1)\end{array}$ & 2361 & $\begin{array}{c}165 \\
(7.0 \%)\end{array}$ & $\begin{array}{c}0.8 \\
(0.7-1.1)\end{array}$ & 2405 & $\begin{array}{c}194 \\
(8.1 \%)\end{array}$ & $\begin{array}{c}0.9 \\
(0.7-1.1)\end{array}$ \\
\hline $25-29$ & 1172 & $\begin{array}{c}53 \\
(4.5 \%)\end{array}$ & 1252 & $\begin{array}{c}61 \\
(4.9 \%)\end{array}$ & $\begin{array}{c}0.9 \\
(0.6-1.3)\end{array}$ & 1308 & $\begin{array}{c}67 \\
(5.1 \%)\end{array}$ & $\begin{array}{c}0.8 \\
(0.6-1.2)\end{array}$ & 1535 & $\begin{array}{c}62 \\
(4.0 \%)\end{array}$ & $\begin{array}{c}0.6 \\
(0.4-0.9)\end{array}$ & 1533 & $\begin{array}{c}72 \\
(4.7 \%)\end{array}$ & $\begin{array}{c}0.6 \\
(0.4-0.9)\end{array}$ \\
\hline $30-34$ & 566 & $\begin{array}{c}14 \\
(2.5 \%)\end{array}$ & 549 & $\begin{array}{c}10 \\
(1.8 \%)\end{array}$ & $\begin{array}{c}0.6 \\
(0.3-1.4)\end{array}$ & 628 & $\begin{array}{c}14 \\
(2.2 \%)\end{array}$ & $\begin{array}{c}0.7 \\
(0.3-1.5)\end{array}$ & 732 & $\begin{array}{c}15 \\
(2.0 \%)\end{array}$ & $\begin{array}{c}0.7 \\
(0.3-1.5)\end{array}$ & 750 & $\begin{array}{c}31 \\
(4.1 \%)\end{array}$ & $\begin{array}{c}1.2 \\
(0.6-2.4)\end{array}$ \\
\hline $35+$ & 762 & $\begin{array}{c}7 \\
(0.9 \%)\end{array}$ & 798 & $\begin{array}{c}11 \\
(1.4 \%)\end{array}$ & $\begin{array}{c}1.3 \\
(0.5-3.3)\end{array}$ & 928 & $\begin{array}{c}10 \\
(1.1 \%)\end{array}$ & $\begin{array}{c}1.1 \\
(0.4-2.8)\end{array}$ & 1249 & $\begin{array}{c}20 \\
(1.6 \%)\end{array}$ & $\begin{array}{c}3.1 \\
(1.3-7.7)\end{array}$ & 1215 & $\begin{array}{c}21 \\
(1.7 \%)\end{array}$ & $\begin{array}{c}3.1 \\
(1.2-7.6)\end{array}$ \\
\hline \multicolumn{15}{|l|}{ Male } \\
\hline $16-19$ & 267 & $\begin{array}{c}27 \\
(10.1 \%)\end{array}$ & 284 & $\begin{array}{c}28 \\
(9.9 \%)\end{array}$ & $\begin{array}{c}1.0 \\
(0.6-1.7)\end{array}$ & 240 & $\begin{array}{c}17 \\
(7.1 \%)\end{array}$ & $\begin{array}{c}0.7 \\
(0.4-1.3)\end{array}$ & 344 & $\begin{array}{c}46 \\
(13.4 \%)\end{array}$ & $\begin{array}{c}1.3 \\
(0.8-2.1)\end{array}$ & 319 & $\begin{array}{c}43 \\
(13.5 \%)\end{array}$ & $\begin{array}{c}1.3 \\
(0.8-2.2)\end{array}$ \\
\hline $20-24$ & 966 & $\begin{array}{c}118 \\
(12.2 \%)\end{array}$ & 1032 & $\begin{array}{c}104 \\
(10.1 \%)\end{array}$ & $\begin{array}{c}0.8 \\
(0.6-1.1)\end{array}$ & 1164 & $\begin{array}{c}147 \\
(12.6 \%)\end{array}$ & $\begin{array}{c}1.0 \\
(0.8-1.3)\end{array}$ & 1341 & $\begin{array}{c}146 \\
(10.9 \%)\end{array}$ & $\begin{array}{c}0.9 \\
(0.7-1.1)\end{array}$ & 1611 & $\begin{array}{c}194 \\
(12.0 \%)\end{array}$ & $\begin{array}{c}1.0 \\
(0.8-1.2)\end{array}$ \\
\hline $25-29$ & 911 & $\begin{array}{c}70 \\
(7.7 \%)\end{array}$ & 1114 & $\begin{array}{c}91 \\
(8.2 \%)\end{array}$ & $\begin{array}{c}1.1 \\
(0.8-1.5)\end{array}$ & 1172 & $\begin{array}{c}88 \\
(7.5 \%)\end{array}$ & $\begin{array}{c}1.0 \\
(0.7-1.3)\end{array}$ & 1414 & $\begin{array}{c}115 \\
(8.1 \%)\end{array}$ & $\begin{array}{c}1.1 \\
(0.8-1.4)\end{array}$ & 1538 & $\begin{array}{c}110 \\
(7.2 \%)\end{array}$ & $\begin{array}{c}0.9 \\
(0.7-1.3)\end{array}$ \\
\hline $30-34$ & 601 & $\begin{array}{c}38 \\
(6.3 \%)\end{array}$ & 667 & $\begin{array}{c}47 \\
(7.0 \%)\end{array}$ & $\begin{array}{c}1.1 \\
(0.7-1.7)\end{array}$ & 650 & $\begin{array}{c}37 \\
(5.7 \%)\end{array}$ & $\begin{array}{c}0.9 \\
(0.6-1.4)\end{array}$ & 803 & $\begin{array}{c}48 \\
(6.0 \%)\end{array}$ & $\begin{array}{c}0.9 \\
(0.6-1.4)\end{array}$ & 864 & $\begin{array}{c}56 \\
(6.5 \%)\end{array}$ & $\begin{array}{c}1.0 \\
(0.7-1.5)\end{array}$ \\
\hline $35+$ & 1169 & $\begin{array}{c}37 \\
(3.2 \%)\end{array}$ & 1250 & $\begin{array}{c}71 \\
(5.7 \%)\end{array}$ & $\begin{array}{c}1.8 \\
(1.2-2.7)\end{array}$ & 1207 & $\begin{array}{c}54 \\
(4.5 \%)\end{array}$ & $\begin{array}{c}1.4 \\
(0.9-2.2)\end{array}$ & 1404 & $\begin{array}{c}75 \\
(5.3 \%)\end{array}$ & $\begin{array}{c}1.7 \\
(1.1-2.5)\end{array}$ & 1437 & $\begin{array}{c}68 \\
(4.7 \%)\end{array}$ & $\begin{array}{c}1.5 \\
(1.0-2.2)\end{array}$ \\
\hline
\end{tabular}

IRR = incidence rate ratio.

3 Percentage of people tested for chlamydia in selected risk profile groups, and change from baseline (2007), by sex and year

\begin{tabular}{|c|c|c|c|c|c|c|c|c|c|c|}
\hline \multirow[b]{2}{*}{ Risk group } & \multicolumn{5}{|c|}{$\% *$ of women meeting risk profile; $\mathrm{OR}^{\dagger}(95 \% \mathrm{Cl})$} & \multicolumn{5}{|c|}{$\% *$ of men meeting risk profile; $\mathrm{OR}^{\dagger}(95 \% \mathrm{CI})$} \\
\hline & 2007 & 2008 & 2009 & 2010 & 2011 & 2007 & 2008 & 2009 & 2010 & 2011 \\
\hline Age $<25$ years & $54.6 \% ; 1$ & $\begin{array}{c}52.4 \% ; 0.9 \\
(0.8-1.1)\end{array}$ & $\begin{array}{c}52.3 \% ; 0.9 \\
(0.7-1.1)\end{array}$ & $\begin{array}{c}50.7 \% ; 0.8 \\
(0.6-1.1)\end{array}$ & $\begin{array}{c}52.7 \% ; 0.9 \\
(0.7-1.1)\end{array}$ & $31.6 \% ; 1$ & $\begin{array}{l}31.1 \% ; 1.0 \\
(0.9-1.1)\end{array}$ & $\begin{array}{l}31.9 \% ; 1.0 \\
(0.9-1.2)\end{array}$ & $\begin{array}{l}31.7 \% ; 1.1 \\
(0.8-1.2)\end{array}$ & $\begin{array}{l}33.4 \% ; 1.1 \\
(0.8-1.4)\end{array}$ \\
\hline Born outside Australia & $34.8 \% ; 1$ & $\begin{array}{l}36.8 \% ; 1.1 \\
(0.9-1.3)\end{array}$ & $\begin{array}{c}39.8 \% ; 1.2 \\
(1.0-1.6)\end{array}$ & $\begin{array}{l}43.8 \% ; 1.5 \\
(1.2-1.9)\end{array}$ & $\begin{array}{l}45.5 \% ; 1.6 \\
(1.1-2.3)\end{array}$ & $33.4 \% ; 1$ & $\begin{array}{c}37.6 \% ; 1.2 \\
(1.2-1.2)\end{array}$ & $\begin{array}{l}40.2 \% ; 1.3 \\
(1.3-1.4)\end{array}$ & $\begin{array}{c}42.8 \% ; 1.5 \\
(1.4-1.6)\end{array}$ & $\begin{array}{c}45.1 \% ; 1.6 \\
(1.5-1.7)\end{array}$ \\
\hline Any STI symptoms at time of test & $40.1 \% ; 1$ & $\begin{array}{c}40.8 \% ; 1.0 \\
(0.9-1.2)\end{array}$ & $\begin{array}{l}42.4 \% ; 1.1 \\
(0.9-1.4)\end{array}$ & $\begin{array}{c}44.9 \% ; 1.2 \\
(1.0-1.5)\end{array}$ & $\begin{array}{l}42.7 \% ; 1.1 \\
(0.8-1.5)\end{array}$ & $43.4 \% ; 1$ & $\begin{array}{c}45.3 \% ; 1.1 \\
(1.0-1.1)\end{array}$ & $\begin{array}{c}48.4 \% ; 1.2 \\
(1.2-1.3)\end{array}$ & $\begin{array}{c}47.8 \% ; 1.2 \\
(1.1-1.3)\end{array}$ & $\begin{array}{l}45.2 \% ; 1.1 \\
(1.0-1.2)\end{array}$ \\
\hline $\begin{array}{l}\text { More than one partner of the } \\
\text { opposite sex in the past } 12 \text { months }\end{array}$ & $60.7 \% ; 1$ & $\begin{array}{l}58.5 \% ; 0.9 \\
(0.7-1.1)\end{array}$ & $\begin{array}{l}61 \% ; 1.0 \\
(0.8-1.4)\end{array}$ & $\begin{array}{l}61.9 \% ; 1.1 \\
(0.9-1.2)\end{array}$ & $\begin{array}{c}67.2 \% ; 1.3 \\
(1.0-1.8)\end{array}$ & $78 \% ; 1$ & $\begin{array}{l}79.6 \% ; 1.1 \\
(1.1-1.1)\end{array}$ & $\begin{array}{c}79.8 \% ; 1.1 \\
(1.1-1.2)\end{array}$ & $\begin{array}{l}78.7 \% ; 1.0 \\
(1.0-1.1)\end{array}$ & $\begin{array}{c}81.4 \% ; 1.2 \\
(1.2-1.3)\end{array}$ \\
\hline $\begin{array}{l}\text { Did not always use condoms with all } \\
\text { partners in the past } 12 \text { months }\end{array}$ & $87.7 \% ; 1$ & $\begin{array}{l}86.4 \% ; 0.9 \\
(0.8-0.9)\end{array}$ & $\begin{array}{l}85.2 \% ; 0.8 \\
(0.7-0.9)\end{array}$ & $\begin{array}{c}86.4 \% ; 0.9 \\
(0.8-1.0)\end{array}$ & $\begin{array}{l}83.4 \% ; 0.7 \\
(0.6-0.8)\end{array}$ & $86.2 \% ; 1$ & $\begin{array}{l}85.7 \% ; 1.0 \\
(0.9-1.0)\end{array}$ & $\begin{array}{l}84.3 \% ; 0.9 \\
(0.8-1.0)\end{array}$ & $\begin{array}{l}85 \% ; 0.9 \\
(0.9-1.0)\end{array}$ & $\begin{array}{l}80.6 \% ; 0.7 \\
(0.7-0.8)\end{array}$ \\
\hline
\end{tabular}

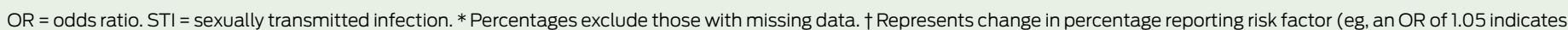
a $5 \%$ increase in the percentage reporting the risk factor each year).

may not be representative of the whole population and may result in a higher prevalence of chlamydia because of the nature of the clinics involved. Positivity varied by clinic type among women tested within the sentinel surveillance system $(6.3 \%$ at sexual health centres and $4.1 \%$ at other clinics). ${ }^{17}$

Supporting the argument that the prevalence of chlamydia is increasing in Australian women, other studies in Australia have also shown an increase in chlamydia rates within their samples. ${ }^{11,13,14}$ While sensitive to rates of testing, surveillance data also support an increase in chlamydia prevalence. ${ }^{1}$ Possible hypotheses explaining a rise in chlamydia prevalence in the population might include decreasing levels of immunity, 18,19 decreased rates of general antibiotic use, ${ }^{20,21}$ increases in treatment failure and reinfections ${ }^{22}$ and increased transmission rates. Increased transmission of chlamydia could be due to an increase in high-risk behaviours, such as higher numbers of sexual partners, increased reporting of casual sex partners and younger age of first sex, which have been shown in other studies in Australia. ${ }^{23,24}$ Our analysis also showed that several risk factors for chlamydia increased among peo- ple tested at sentinel sites between 2007 and 2011. The exception was a decline in reporting of inconsistent condom use; however, an overwhelming majority of respondents (85\%) reported that they did not use condoms consistently.

In conclusion, we identified an increase in chlamydia positivity over time, particularly among young women. Explanations for this trend may include changes in behaviours, leading to increased risk of transmission or an increase in the number of women at high risk presenting for testing. The continued emphasis on young women is warranted, and 
chlamydia screening is important; however, public health measures need to go beyond testing to target highrisk sexual behaviours.

Acknowledgements: We thank patients attending sentinel sites and the clinicians, scientists and other staff at participating sentinel clinics and laboratories for their contribution to the Victorian Primary Care Network for Sentinel Surveillance (VPCNSS) on bloodborne viruses and STIs. The Department of Health Victoria provides funding support for VPCNSS. Megan Lim is supported by an NHMRC Early Career Researcher Fellowship. Margaret Hellard is supported by an NHMRC Research Fellowship. Maelenn Gouillou and Paul Agius assisted us in statistical analysis and data management. We gratefully acknowledge the contribution to this work of the Victorian Operational Infrastructure Support Program received by the Burnet Institute.

Competing interests: Participating sites (including Barwon Sexual Health Centre, Young People's Health Service and Family Planning Victoria) were paid \$1 per completed survey form.

Received 23 Jan 2013, accepted 22 Aug 2013.

1 Department of Health and Ageing. National Notifiable Diseases Surveillance System. 2011. http://www9.health.gov.au/cda/Source/CDAindex.cfm (accessed Jun 2013).

2 Pedrana A, Hellard M, Guy R, et al. Stop the drama Downunder: a social marketing campaign increases HIV/sexually transmitted infection knowledge and testing in Australian gay men. Sex Transm Dis 2012; 39: 651-658.

3 Gold J, Goller J, Hellard M, et al. Impact evaluation of a youth sexually transmissible infection awareness campaign using routinely collected data sources. Sex Health 2011; 8: 234-241.

4 Martin L, Freedman E, Burton L, et al. The Cproject: use of self-collection kits to screen for Chlamydia trachomatis in young people in a community-based health promotion project. Sex Health 2009; 6: 157-162.
5 Kong FY, Hocking JS, Link CK, et al. Sex and sport: chlamydia screening in rural sporting clubs. BMC Infect Dis 2009; 9: 73.

6 Buhrer-Skinner M, Muller R, Bialasiewicz S, et al. The check is in the mail: piloting a novel approach to Chlamydia trachomatis testing using selfcollected, mailed specimen. Sex Health 2009; 6: 163-169.

7 Lister NA, Smith A, Read T, Fairley CK. Testing men who have sex with men for Neisseria gonorrhoeae and Chlamydia trachomatis prior to the introduction of guidelines at an STD clinic in Melbourne. Sex Health 2004; 1: 47-50.

8 Walker J, Fairley CK, Walker SM, et al. Computer reminders for chlamydia screening in general practice: a randomized controlled trial. Sex Transm Dis 2010; 37: 445-450.

9 Medicare Australia. Medicare item reports [online database]. https: //www.medicareaustralia. gov.au/statistics/mbs item.shtml (accessed Aug 2013).

10 O'Rourke KM, Fairley CK, Samaranayake A, et al. Trends in chlamydia positivity over time among women in Melbourne Australia, 2003 to 2007. Sex Transm Dis 2009: 36: 763-767.

11 Vodstrcil LA, Fairley CK, Fehler G, et al. Trends in chlamydia and gonorrhea positivity among heterosexual men and men who have sex with men attending a large urban sexual health service in Australia, 2002-2009. BMC Infect Dis 2011; 11: 158.

12 Donovan B. Rising prevalence of genital Chlamydia trachomatis infection in heterosexual patients at the Sydney Sexual Health Centre 1994 to 2000. Commun Dis Intell Q Rep 2002; 26 : $51-55$.

13 Ali H, Guy RJ, Fairley CK, et al. Understanding trends in genital Chlamydia trachomatis can benefit from enhanced surveillance: findings from Australia. Sex Transm Infect 2012; 88 : 552-557.

14 Grulich AE, de Visser RO, Smith AM, et al. Sex in Australia: sexually transmissible infection and blood-borne virus history in a representative sample of adults. Aust N Z J Public Health 2003; 27: 234-241.

15 LaMontagne DS, Fenton KA, Randall S, et al. Establishing the National Chlamydia Screening Programme in England: results from the first full year of screening. Sex Transm Infect 2004; 80: 335-341.

16 Goller JL, Guy RJ, Gold J, et al. Establishing a linked sentinel surveillance system for bloodborne viruses and sexually transmissible infections: methods, system attributes and early findings. Sex Health 2010; 7: 425-433.

17 Lim MS, Goller JL, Guy R, et al. Correlates of Chlamydia trachomatis infection in a primary care sentinel surveillance network. Sex Health 2012; 9 : 247-253.

18 Batteiger BE, Xu F, Johnson RE, Rekart ML. Protective immunity to Chlamydia trachomatis genital infection: evidence from human studies. J Infect Dis 2010; 201 Suppl 2: S178-S189.

19 Atik B, Thanh TT, Luong VQ, et al. Impact of annual targeted treatment on infectious rachoma and susceptibility to reinfection. JAMA 2006; 296: 1488-1497.

20 Medicare Australia. Pharmaceutical Benefits Schedule group reports [online database]. 2012 https://www.medicareaustralia.gov.au/ statistics/pbs group.shtml (accessed Oct 2012).

21 Australian Bureau of Statistics. 2011 Census QuickStats. 2011. http://www.censusdata.abs. gov.au/census_services/getproduct/census/2011/ quickstat/2?opendocument\&navpos $=220$ (accessed Oct 2012)

22 Batteiger BE, Tu W, Ofner S, et al. Repeated Chlamydia trachomatis genital infections in adolescent women. J Infect Dis 2010; 201: 42-51.

23 Lim MS, Bowring AL, Gold J, et al. Trends in sexual behavior, testing, and knowledge in young people; 2006-2011. Sex Transm Dis 2012; 39: 831-834.

24 Rissel CE, Richters J, Grulich AE, et al. Sex in Australia: first experiences of vaginal intercourse and oral sex among a representative sample of adults. Aust NZ J Public Health 2003;27:131-137. •

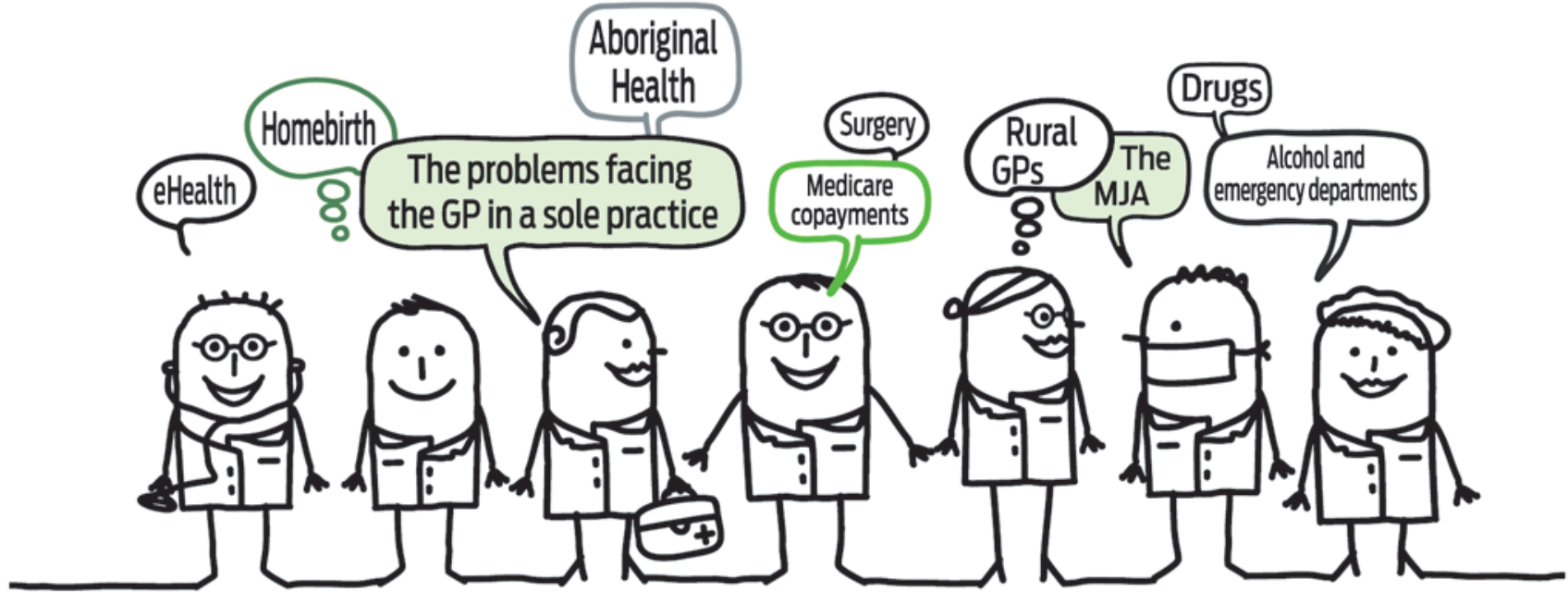

Got something to say? Have your comments printed in the MJA! See page 135 for full details. 